\title{
The Genes for Major Psychosis: Aberrant Sequence or Regulation?
}

\author{
Arturas Petronis, M.D., Ph.D.
}

A number of recent clinical and molecular observations in major psychosis indicate that epigenetic factors may be operational in the origin of major mental illness. This article further develops the idea that epigenetic factors may play an etiopathogenic role in schizophrenia and bipolar affective disorder. The putative role of epigenetic factors is shown by the epigenetic interpretation of genetic association studies of the genes for serotonin 2A (HTR2A) and the dopamine D3 (DRD3) receptors in schizophrenia. The idea of epigenetic polymorphism of genetic alleles is introduced, and it is argued that epigenetic variation may explain a number of controversial and unclear findings in allelic and genotypic association studies of HTR2A and DRD3. In linkage analyses of multiplex families with bipolar affective disorder (BPAD), different loci on chromosome 18 indicated co-segregation of alleles of one parental sex with the disease phenotype, and this finding implies that the epigenetic mechanism of genomic imprinting may be involved. Evidence for genomic imprinting provides the background for epigenetic cloning of BPAD risk factors by searching for differentially modified genes on chromosome 18. Finally, epigenetic studies could be relevant to the better understanding of the molecular action of antipsychotic medications. In addition to this, if epimutations are detected in major psychosis, epigenetic treatment directed at correction of epigenetic status of a specific brain gene may eventually be developed. [Neuropsychopharmacology 23: 1-12, 2000] (c) 2000 American College of Neuropsychopharmacology. Published by Elsevier Science Inc. All rights reserved

of epigenetic mechanisms has been uncovered, and a series of important functions of genome regulation have been ascribed to epigenetic DNA modification (Bestor et al. 1994, Riggs and Porter 1996). Epigenetic mechanisms can explain a number of clinical and molecular findings that traditionally have been supporting unrelated and somewhat antagonistic theories of major psychosis (Petronis et al. 1999). In this article, we further develop the epigenetic theory and re-analyze a number of experimental findings in psychiatric genetics that suggest a series of candidate genes and chromosomal loci that may become the targets for epigenetic studies.

\section{SEROTONIN 2A RECEPTOR GENE (HTR2A) \\ AND SCHIZOPHRENIA} Health, and Department of Psychiatry, University of Toronto, Toronto, Ontario, Canada.

Address correspondence to: Dr. A. Petronis, Neurogenetics Section, R-28, Centre of Addiction and Mental Health, 250 College St., Toronto, Ontario M5T 1R8, Canada; Tel: 416-535-8501, ext. 4880; Fax: 416-979-4666; E-mail: arturas_petronis@camh.net

Received March 3, 2000; revised April 5, 2000; accepted April 10, 2000.

\section{Current Status of HTR2A Studies in Schizophrenia} cades ago when it was detected that serotonin is widely
Interest in serotonin system genes arose several de- 
distributed throughout the central nervous system and that the hallucinogenic drug LSD demonstrates high affinity for serotonin receptors (reviewed in Lewis et al. 1999). To our knowledge, association of HTR $2 A$ with SCZ was first detected in a Japanese sample when a higher frequency of $C$ allele of the $102 \mathrm{~T} / \mathrm{C}$ polymorphism was documented (Inayama et al. 1996). Although a number of studies with relatively small sample sizes were negative, a large combined study consisting of over a thousand SCZ patients and ethnically matched controls detected a significant overall association between SCZ and the $102 \mathrm{C}$ allele $(p=.003 ; \mathrm{OR}=1.3 ; 95 \%$ CI 1.1-1.53; Williams et al. 1996). In addition to the higher rate of allele $102 \mathrm{C}$ among SCZ patients, there also existed a statistically significant excess of T-C and $\mathrm{C}-\mathrm{C}$ genotypes versus T-T genotypes in SCZ $(p=.008)$ with a relative risk of 1.7 (95\% CI 1.22-2.36). Analytical approaches that are rigorous to population stratification, specifically transmission disequilibrium test, partially confirmed the case-control findings that the 102C allele is associated with SCZ (Spurlock et al. 1998a, but see also, Hawi et al. 1997). A meta-analysis of 15 studies including 1533 patients and 1771 controls, detected a significant excess of $102 \mathrm{C}$ allele in patients $(p=.0009$; $\mathrm{OR}=1.18 ; 95 \%$ CI 1.07-1.31) with no evidence for heterogeneity between studies (Williams et al. 1997). Although both case-controls studies (Kidd 1993) and meta-analyses (Sharpe 1997) have been criticized, and therefore the results of such studies should be interpreted with caution, at present rejecting the etiological role of the HTR2A in SCZ with absolute certainty is impossible (O'Donovan and Owen 1999).

The nature of the $102 \mathrm{~T} / \mathrm{C}$ polymorphism, however, does not help for further understanding of the controversies of association studies. 102T/C polymorphism does not alter the amino acid sequence in the serotonin $2 \mathrm{~A}$ receptor which means that the receptors encoded by $102 \mathrm{C}$ alleles have exactly the same structure as the ones encoded by $102 \mathrm{~T}$ alleles. Several other possibilities that would explain the role of the $102 \mathrm{~T} / \mathrm{C}$ polymorphism in SCZ have been suggested. First, it has been hypothesized that mRNA transcribed from the 102T allele may exhibit different secondary structure in comparison to mRNA transcribed from the $102 \mathrm{C}$ allele, which may affect the efficiency of translation (Arranz et al. 1995). Direct studies of mRNA of the $102 \mathrm{C}$ and $102 \mathrm{~T}$ alleles have not been performed, however indirect ones did not support the latter hypothesis as no difference in serotonin $2 \mathrm{~A}$ receptor density in the frontal cortex was detected in individuals carrying $102 \mathrm{~T}$ versus $102 \mathrm{C}$ alleles (Kouzmenko et al. 1997). The second possibility is that the real "culprit" polymorphism or mutation might be in linkage disequilibrium with the $102 \mathrm{~T} / \mathrm{C}$ polymorphism. Several polymorphisms in the exons of HTR2A were detected but none of them were associated with SCZ (Erdmann et al. 1996). The search for polymorphisms was later extended to the $5^{\prime}$-region of the gene, which resulted in detection of another polymorphism $(-1438) A / G$. Although $(-1438) A / G$ is in linkage disequilibrium with $102 \mathrm{~T} / \mathrm{C}$, the former polymorphism does not exhibit significant differences in the promoter basal activity (Spurlock et al. 1998a), and, therefore, cannot explain the association between HTR2A and SCZ. In HTR2A expression studies, post-mortem brains showed that amounts of HTR $2 A$ mRNA were roughly $50 \%$ lower in a number of cortical regions in SCZ patients compared to controls (Burnet et al. 1996). In addition, a number of studies (although not all) detected decreased density of serotonin receptors $\left(B_{\max }\right)$ but no changes in receptor affinity $\left(K_{d}\right)$ in the brains of SCZ patients compared to controls (reviewed in Lewis et al. 1999). Changes in $B_{\max }$ but not $K_{d}$ suggest that serotonergic dysfunction in $\mathrm{SCZ}$ is more likely to represent regulatory problems at the HTR $2 A$ rather than a structural mutation in the protein coding region

\section{Epigenetic Interpretation of HTR2A Studies with SCZ}

Origin of the "T102C" Polymorphism. From the epigenetic point of view, the 102C (CCG) allele, but not the $102 \mathrm{~T}$ allele (CTG), is more likely to be the ancestral allele (Clifford and Nunez 1996). This argument is based on the observation that different nucleotides exhibit differential mutability rates. More specifically, CCG $\rightarrow$ CTG substitution rate is 4.5 times higher than the rate of CTG $\rightarrow$ CCG, while its homologue CGG mutates to CAG 16 times more often than the reverse CAG $\rightarrow$ CGG (Krawczak et al. 1998, Table 4, p. 480). The fact that chimpanzee's genotype at this site is C-C (Cargill et al. 1999) finally proves that CCG, but not CTG, is the ancestral allele. The mechanism of $\mathrm{C} \rightarrow \mathrm{T}$ mutation may be of epigenetic origin since methylated cytosine $\left({ }^{\mathrm{met}} \mathrm{C}\right)$ in the $\mathrm{CpG}$ dinucleotide is known to be a "hot" spot for DNA mutation (Yang et al. 1996), and it is likely that the $\mathrm{C} 102 \mathrm{~T}$ polymorphism resulted from the conversion of ${ }^{\mathrm{met}} \mathrm{C}$ to uracil and eventually to thymine. The (-1438)A/G polymorphism may be of the same genesis since the complementary strand of $A / G$ is $\mathrm{T} / \mathrm{C}$, with $\mathrm{T}$ flanked by $\mathrm{C}$ and $\mathrm{G}$.

The latter assumption (that $102 \mathrm{C}$ allele but not $102 \mathrm{~T}$ one is the ancestral allele), however, runs into a paradox that the ancestral allele is the risk factor for SCZ, and the frequency of the risk allele in some populations exceeds $50 \%$ (He et al. 1999). The fact that more than two-thirds of a population carries the risk allele was used as an argument against HTR2A being involved in SCZ (Crow 1996). The analysis of epigenetic status at HTR2A may help understanding this and other unclear issues around the role of HTR $2 A$ in SCZ, and the idea of $H T R 2 A$ epigenetic variation is described below.

Polymorphic Genomic Imprinting of HTR2A. Evidence that epigenetic factors may play a role in regulation of 
HTR2A, has been recently provided (Kato, Shimizu, et al. 1996). It was found that HTR2A was expressed only in the human fibroblast tissue culture with a maternal allele but not in the cells without a maternal allele (Kato, Shimizu, et al. 1996). Such parent of origin specific monoallelic expression of the gene may represent genomic imprinting at HTR2A. By definition, genomic imprinting refers to parent-of-origin dependent epigenetic marking of genes that results in differential expression of such genes (for review see Barlow 1995, Falls et al. 1999, Joyce and Schofield 1998, Ohlsson et al. 1998, Solter 1998). The alleles of imprinted genes appear to be differentially marked during gametogenesis or during the early part of development, and such epigenetic marks are reversible from generation to generation. Consistent with the idea of genomic imprinting, the $5^{\prime}$ region of HTR $2 A$ was methylated in cells with the maternal gene, and it was not methylated in cells without the maternal gene (Kato, Shimizu, et al. 1996). The fact that the experiment was performed in non-native cells raises the additional question if epigenetic regulation of HTR2A in the fibroblast tissue culture is the same as in the native tissue. We recently demonstrated that gene methylation status may change after the transformation of peripheral lymphocytes with the Epstein-Barr virus (Petronis et al. in press). Although generally important, this concern seems to not be critical in the case of HTR2A because at least two other studies demonstrated converging evidence for mono-allelic expression and possible genomic imprinting of HTR2A. In one of them, it was shown that the mouse homologue, Htr2, exhibits genomic imprinting with expression of maternal alleles only in the tissues where this gene is expressed (Kato et al. 1998). The analysis of human brain tissues showed that some individuals exhibit monoallelic expression but in the absence of information about parental origin of such alleles, a stronger conclusion about genomic imprinting could not be drawn (Bunzel et al. 1998). It is important to note that only four out of 18 tested brain tissues exhibited monoallelic HTR2A expression, while in the remaining 14 tissues HTR2A was expressed biallelically (Bunzel et al. 1998). Such irregularity of imprinting is called polymorphic genomic imprinting, and has already been described for other human genes, such as the genes for insulin-like growth factor II (IGF2; Xu et al. 1993) and Wilms tumor (WT1; Jinno et al. 1994). The origin of polymorphic genomic imprinting is not clear.

Polymorphic genomic imprinting of $H T R 2 A$ can be a significant confounding factor in genetic association studies. It is critically important to know how many individuals express both HTR2A alleles and how many individuals express only one HTR2A allele in the groups of controls and affected subjects (see Figure 1). None of the numerous association studies of HTR2A in SCZ accounted for the polymorphic genomic imprinting, which questions the validity of such studies.

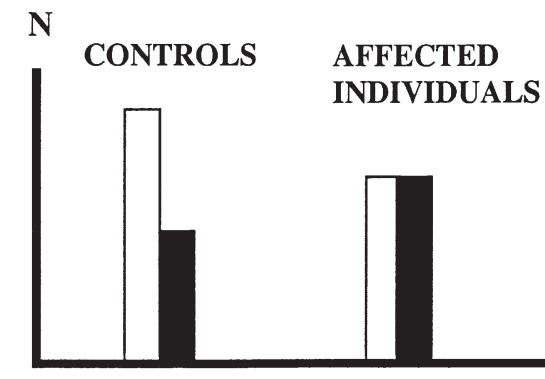

\section{Individuals with biallelic expression of $H T R 2 A$}

Individuals with monoallelic expression of HTR2A

Figure 1. Monoallelic and biallelic expression of HTR2A. The proportions of monoallelically and biallelically expressed HTR $2 A$ may be different in controls and affected individuals.

Other Types of Epigenetic Polymorphism at the HTR2A. In addition to genomic imprinting, the $e x$ pressing $H T R 2 A$ alleles may be subjected to other types of epigenetic regulation. In our recent studies of the dopamine D2 receptor gene (DRD2) we showed that each DNA sample exhibited a unique pattern of DNA methylation at the 5'-region of DRD2 with a high degree of somatic variability of ${ }^{\mathrm{met}} \mathrm{C}$ (Popendikyte et al. 1999). There were no two DNA samples with identical patterns of $D R D 2$ methylation, which is not surprising given the metastable nature of epigenetic signals. In a similar way to genetic polymorphism, which refers to DNA sequence differences across individuals, variation of epigenetic patterns can be called epigenetic polymorphism. The idea of epigenetic polymorphism suggests that in addition to "yes/no" type regulation by genomic imprinting, a "many shades of grey"-type epigenetic regulation may be present in HTR2A. A combination of the two types of regulation, polymorphic imprinting and epigenetic polymorphism, may account for differential degree of HTR $2 A$ expression across individuals.

The epigenetic polymorphism may help explain the role of HTR2A 102C/T polymorphism in SCZ in the following way. A sample of $102 \mathrm{C}$ alleles, although they possess identical DNA sequence, may be different from the epigenetic point of view. Some of the $102 \mathrm{C}$ alleles may be heavily methylated in their regulatory regions and, therefore, expressed to a relatively low degree, while other 102C alleles may be hypomethylated, which results in high expression of the gene. The same idea is applicable to $102 \mathrm{~T}$ alleles. Such epigenetic variants of genetic alleles can be called epialleles. 102C and 102T epialleles that are beyond some critical "threshold" level of epigenetic modification may be predisposing to SCZ. Evidence for genetic association is detected because on average one type of alleles (e.g., 102C) is subjected to a stronger epigenetic suppression of gene expression than the other alleles (e.g., 102T). In this scenario, a genetic 
polymorphism does not have any biological effects, and such genetic variation is nothing but a "reporter" of the epigenetic status of an allele. The idea of a genetic reporter of epigenetic status was recently developed to explain the association between $\mathrm{TaqI} \mathrm{I}^{\prime} \mathrm{A}$ " polymorphism of $D R D 2$ and D2 receptor density in the brain (Petronis 1999), where it was suggested that DRD2 TaqI"A" polymorphism resulted from the mutation of a methylated $C$ $\left({ }^{\mathrm{met}} \mathrm{C}\right)$, which is a "hot" spot for DNA mutation (Yang et al. 1996) and which led to the rarer TaqI" $\mathrm{A}^{\prime \prime}$ allele, TTGA. It was hypothesized that various DRD2 alleles (haplotypes) are subjected to various patterns of DNA methylation around the TaqI" $\mathrm{A}^{\prime \prime}$ polymorphic site. In this case, the di-allelic TaqI" $A$ " site serves only as a reporter of the epigenetic status of the region surrounding the TaqI " $\mathrm{A}$ " site. The role of a reporter may eventually degenerate because each meiosis evokes a major rearrangment of epigenetic status in the gametes (Holliday 1996; Shemer and Razin 996), and the epigenetic status of DRD2 may undergo significant changes. At some point, polymorphic DNA sites may fail to represent the epigenetic modification of a specific DRD2 allele (Petronis 1999). For the same reason, absence of DRD2 linkage to SCZ and controversial results in $D R D 2$ genetic association studies do not exclude the putative role of epigenetic regulation in the etiopathogenesis of the disease.

The same argument is applicable to the C102T polymorphism for HTR2A. As discussed above, the 102T allele may have originated from deamination of ${ }^{\text {met }} \mathrm{C}$ to uracil and eventually to thymine. The discriminatory power of the C102T polymorphism of the epigenetic variation of genes may vary across populations and samples. The higher the epigenetic difference between 102C and $102 \mathrm{~T}$ alleles, the stronger evidence for association with SCZ. Samples with a negligible difference in epigenetic status across $102 \mathrm{C}$ and $102 \mathrm{~T}$ alleles will exhibit no association with SCZ. The relationship between genetic and epigenetic association is graphically represented in Figure 2. The idea of epigenetic dysregulation of HTR2A in SCZ is consistent with the decreased amounts of HTR2A mRNA (Burnet et al. 1996) and serotonin receptor type 2 density $\left(B_{\max }\right)$ (Lewis et al. 1999) in post-mortem brains of SCZ patients compared to controls.

\section{DOPAMINE D3 RECEPTOR GENE (DRD3) AND SCHIZOPHRENIA}

$D R D 3$ has been one of the most popular genes in genetic association studies of SCZ. The BalI (or MscI) polymorphism represents a serine (Ser) to glycine (Gly) substitution in the codon 9 of the first exon of DRD3. Since the primary finding of increased homozygosity of BalI alleles among SCZ patients (Crocq et al. 1992), this polymorphism has been analyzed in more than 30 independent studies. Although individual studies with relatively small sample sizes led to quite controversial conclusions, a large European study using more than 300 SCZ cases and controls, replicated the excess of DRD3 homozygotes of both alleles in SCZ patients $(p=.003$; Spurlock et al. 1998b). Several meta-analyses have been performed, and these have supported the risk effect of DRD3. One of them detected excess of Ser/Ser carriers among SCZ patients in the both African and Caucasian groups ( $p<.05$; Dubertret et al. 1998). Another metaanalysis which investigated a sample of 5351 individuals, detected a significant excess of both forms of homozygotes in the group of SCZ patients ( $p=.0009$; Williams et al. 1998). A transmission disequilibrium test showed a significant excess of both homozygotes in SCZ patients ( $p=.004$; Williams et al. 1998). The above findings suggest that either homozygosity of DRD3 BalI

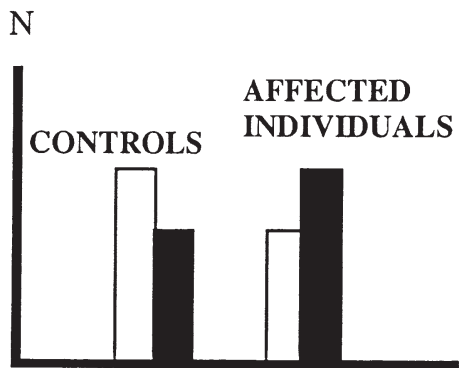

Allele 1

Allele 2

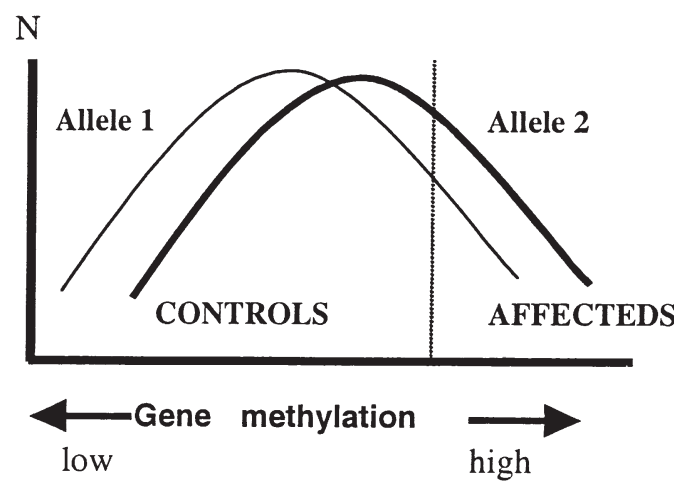

Figure 2. Genetic and epigenetic association with a disease. (A) Distribution of alleles 1 and 2 in the groups of affected individuals and controls. Allele 2 is associated with a disease. (B) Distribution of alleles 1 and 2 according to their epigenetic status. Both alleles exhibit a normal distribution of epialleles, although the mean degree of DNA methylation of allele 2 (thick line) is higher in comparison to allele 1 (thin line). Punctuated vertical line represents a hypothetical threshold at which epialleles begin to noticeably increase the risk of a disease. Epialleles of both alleles predispose to a disease, however the proportion of epialleles 2 is greater than that of epialleles 1 . 
is a predisposing condition to $\mathrm{SCZ}$, or heterozygosity for alleles for this DRD3 polymorphism is a protective factor. This effect is called overdominance (also "heterosis" or "hybrid vigor"). At least three samples studied in two centers showed a sex effect, that is, significant excess of homozygotes was observed in males ( $p=$ 0.00021) but not in females (Asherson et al. 1996, Griffon et al. 1996).

In DRD3 expression studies, cortical regions of postmortem brains from patients affected with SCZ revealed significantly lower levels of D3 mRNA than in controls (Meador-Woodruff et al. 1997). Interestingly, the expression of a D3 splicing variant named D3nf (a truncated D3 variant that differs from the D3-receptor only in the carboxyl terminus) appeared to be unaffected in SCZ brains (Schmauss et al. 1993, Schmauss 1996). It was suggested that disproportion between D3nf and regular D3 proteins may affect efficiency of the formation of heteroligomeric D3 complexes (Nimchinsky et al. 1997) which potentially disturb dopaminergic function in the brain of $\mathrm{SCZ}$ patients.

\section{Epigenetic Interpretation of the DRD3 Findings in SCZ}

The easiest finding to explain from the epigenetic point of view is the presence of $D R D 3$ association in the group of SCZ males, but absence of such association in the SCZ females. Differential effects of hormones, including sex hormones, have a significant impact on gene expression, and this is achieved by changing chromatin conformation (Jantzen et al. 1987, Truss et al. 1992) and/or local pattern of gene methylation (Saluz et al. 1986). Some genes exhibit even a clear-cut sexually dimorphic DNA methylation pattern (Yokomori et al. 1995).

The role of epigenetic factors in other DRD3 findings in SCZ is not straightforward. Despite numerous phenotypic observations of overdominance, molecular mechanisms of this phenomenon are not clear, and experimental studies on this issue are sparse. A classical example of overdominance is that related to the heterozygous condition of the gene encoding the $B$ chain of hemoglobin $(H B B)$. DNA mutations that lead to replacement of amino acid sequence in $H B B$, significantly reduce the ability of $\mathrm{Hb}$ protein to bind oxygen, and homozygosity for $H B B$ mutation leads to a recessive disease, sickle cell anemia. Sickle cell trait, or heterozygosity for the recessive mutation in $H B B$, is evolutionary advantageous because a wild type allele provides an organism with a normal supply of oxygen while the presence of a mutant allele significantly reduces the risk for malaria. The example of sickle cell trait, however, is hardly applicable to the DRD3 findings in SCZ. Mutant and wild-type $H B B$ homozygotes are susceptible to two very different diseases, while in the case of $D R D 3$ it is the same disease. At the molecular level, mutant hemoglobin exhibits a very different affinity for oxygen in comparison to the wild hemoglobin, while the recep- tors deriving from Ser and Gly alleles of DRD3 exhibit only marginal, if any, difference in their affinity for dopamine (Lundstrom and Turpin 1996). In addition, there is no evident difference in the expression of mutant $H B B$ alleles in comparison to wild-type alleles, at least at the protein level, while $D R D 3$ expression seems to be disturbed in SCZ. All these differences allow for thinking that overdominance of D3 receptor in SCZ is mechanistically different from the one in the sickle cell trait. Can it be epigenetic?

In the literature, there are at least two examples that relate overdominance to epigenetic regulation of gene expression. Expression of $P l^{\prime}-m a h$, an epiallele of a maize transcriptional regulator gene for antocyanin synthesis, may vary depending on the second $p l$ allele (Hollick and Chandler 1998). Expression of $\mathrm{Pl}^{\prime}-\mathrm{mah}$ is relatively low and is stable when this epiallele is homozygous or heterozygous with another epiallele, $\mathrm{Pl}$ $R h$, but such expression increases significantly when it appears in combination with other $p l$ alleles or when $\mathrm{Pl}^{\prime}$-mah is hemizygous (Hollick and Chandler 1998). Such a significantly higher expression of $P l^{\prime}-$ mah in a combination with $p l$ alleles cannot be explained by a simple additive effect of $P l^{\prime}-m a h$ and $p l$ alleles, and is likely to represent a case of overdominance. The increase in $P l^{\prime}-m a h$ expression is thought to be related to the absence of allelic interaction between $P l^{\prime}-m a h$ and $p l$ alleles while epialleles $P l^{\prime}-m a h$ and $P l-R h$ are likely to "communicate" with each other, which sustains relatively low level of $P l^{\prime}-m a h$ expression.

In addition to plants, evidence for epigenetic factors in overdominance derives from the genetic studies of callipyge sheep that exhibit the phenotype of muscular hypertrophy (Cockett et al. 1996). Molecular studies have shown that only heterozygous sheep (CLPG/cplg) that inherited the callipyge mutation, but not homozygous carriers of the mutant alleles (CLPG/CLPG), expressed the phenotype of muscular hypertrophy (Cockett et al. 1996). The idea that CLPG overdominance might be of epigenetic origin is based on the fact that the cplg locus exhibits strong evidence for genomic imprinting since only matings with CPLG rams, but not CPLG ewes, produced offspring with muscular hypertrophy. Although it would be naïve to directly extrapolate from plant and animal findings to $D R D 3$ studies in $\mathrm{SCZ}$, given the lack of alternative explanations, epigenetic analyses may be one of the possible approaches.

The epigenetic mechanism of DRD3 overdominance becomes even more complicated if reduced expression of DRD3 is a result of abnormal splicing of D3 mRNA. In this case, the putative role of epigenetic factors derives from the observation that sites of gene transcription and mRNA splicing co-exist in the nuclear compartments (Moen et al. 1995, Zirbel et al. 1993), which favors the idea that the two processes are temporally and spatially linked in the cell nucleus. It has also been 
suggested that nuclear compartmentalization is an epigenetic mechanism (Riggs and Porter 1996), and, therefore, the epigenetic factors may play a role in the further processing of mRNAs. At least two experimental studies suggested the role of DNA template-based (cis) factors but not cytoplasmatic (trans) factors in alternative splicing (Adami and Babiss 1991, Hayward et al. 1998). The first study demonstrated that different spliced versions of the E1B gene may originate from late and early adenoviral genomes which co-existed in the same cell. Neither genome was able to impose its regulated splicing pattern on the other, indicating that the cue for the switch in viral gene splicing is not directly dependent on global changes in trans-acting splicing factors. This suggests a model where the signal for changes in RNA processing for the E1B is linked to the state of the DNA template or its localization within nuclear subcompartments. Another example comes from human GNAS1, the gene that encodes maternally, paternally, and biallelically derived proteins. It was shown that mRNA of the paternally derived large G protein, $\mathrm{XL}$, is differentially spliced in comparison to the mRNA transcripts of the neuroendocrine secretory protein NESP55, which is expressed exclusively from the maternal allele. In addition, consistently with the idea of epigenetic influence on differential splicing, a series of genes were shown to exhibit tissue-specific and developmental stage-specific expression o particular alternative mRNA molecules (Lopez 1998). Both tissue specificity and developmental changes are known to be epigenetic functions, and it can be hypothesized that concomitant alterations in the gene splicing patterns may also be related to epigenetic modification of the genome.

\section{CHROMOSOME 18 AND BIPOLAR AFFECTIVE DISORDER}

Chromosome 18 in bipolar affective disease (BPAD) is interesting from at least two points of view. This chromosome exhibits evidence for linkage in a proportion of bipolar disease families, and some linked loci on chromosome 18 demonstrate parent-of-origin effects. Excess sharing of the paternal but not maternal alleles was observed at D18S41, a marker on chromosome 18q21 in bipolar and recurrent unipolar depression $(p=.0004$; Stine et al. 1995). When only paternal pedigrees (i.e., when those in which the father or one of the father's sibs is affected), the same marker, D18S41, showed even greater degree of allele sharing $(81 \% ; p=.00002$; LOD $=$ $3.51 ; 2=0.0$; Stine et al. 1995). Interestingly, D18S464, a marker on 18p11, showed evidence for linkage to exclusively maternal alleles $(p=.02$ and $p=.004$ for bipolar and recurrent unipolar depression, and for bipolar disease, respectively; Stine et al. 1995). As expected in complex traits, effort to replicate the above finding led to quite controversial results (Van Broeckhoven and Verheyen 1998, 1999). Several studies, however, could not reject the hypothesis that parental-sex specific genetic factors on chromosome 18 markers contribute to etiology of BPAD. In a new family collection the Johns Hopkins University group detected excess sharing of paternal alleles among BPAD patients at the markers D18S38 (68\%; $p=.054)$ and D18S541 (78\%; $p=.015$; McMahon et al. 1997) which are $\sim 7 \mathrm{cM}$ and $\sim 18 \mathrm{cM}$ distal to D18S41 on the male-specific genetic map (see http:/ /cedar.genetics.soton.ac.uk/public_html), respectively. Another study detected that mixed paternalmaternal families showed evidence for linkage to chromosome 18 centromeric markers to BPAD, in the region D18S37-D18S56 (affected sib pair method, $p$ values from $10^{-5}$ to 0.03 for different markers), but no evidence for linkage was detected in pure maternal families (Gershon et al. 1996). This finding has recently been confirmed using multipoint ASPEX analysis (DeteraWadleigh et al. 1999).

Parent-of-origin effect has been investigated in several combined studies of linkage data on chromosome 18 in BPAD from several centers in North America (including the above) and in Europe (Rice 1997). Linkage results varied widely depending on selection of datasets, statistical approaches used for meta-analysis, linkage parameters, and phenotypic definition of the disease (Collins and Go 1997, Donald et al. 1997, Greenwood and Bull 1997, Lin and Bale 1997), with the overall conclusion that parent-of-origin effect cannot be excluded for chromosome 18p and 18q markers in BPAD.

Interestingly, parent-of-origin effect for BPAD has been suggested in clinical studies. The risk for BPAD was significantly higher for maternal relatives $(p=$ .006), and for the offspring of affected mothers ( $p=$ .017), while effected fathers repeatedly failed to transmit the disease to their daughters or sons (McMahon et al. 1995). The maternal effect was replicated in some studies (Gershon et al. 1996), while in others the size of maternal effect depended on the definition (boundaries) of the disease phenotype (Kato, Winokur, et al. 1996) or was not seen at all (Grigoroiu-Serbanescu et al. 1998). A cautionary note is that some of the above BPAD samples were ascertained for linkage analysis, and population-based studies are necessary for verification of the risk for BPAD depending on the sex of affected parent. On the other hand, females are more commonly affected with BPAD than males; therefore, lower genetic loading should be required for females to reach the threshold of clinical disease, which should result in lower disease risk to maternal but not paternal offspring; the opposite observation suggests that genuine genomic imprinting is operating in BPAD.

Clinical findings of parent-of-origin effect have direct implications for linkage studies in BPAD because 
these indicate that at least some chromosomal loci may exhibit differential linkage depending on their parental origin. No contradiction exists between the evidence for maternal effect in BPAD families and paternal effect in linkage analysis to chromosome 18 markers in BPAD. The paternal effects on chromosome 18 may be outweighed by more common maternal genetic risk factors on other chromosomes, which results in the overall evidence for preferential maternal transmission of BPAD. The above studies suggest that linkage analyses have to be performed in a parental sex-specific way, that is, excess of allele sharing has to be sought for maternal and paternal alleles separately.

Parent-of-origin specific linkage analyses have at least two advantages in comparison to the ones that ignore parental origin of alleles. First, random co-segregation with disease phenotype is unlikely to be limited to the same-sex parents. Given that evidence for linkage in complex diseases is usually weak, and that it is always difficult to differentiate between a true predisposing locus and a false positive, parent-sex specific linkage may be of significant heuristic value. "Lukewarm" linkage that derives from a parent of one sex may be of greater importance than the same evidence of linkage that originates from both parents. Similarly, the idea of parental effect was creatively applied to a controversial phenomenon of genetic anticipation (increased severity and earlier age of a disease onset in subsequent generations). Several years before the discovery of unstable DNA, it was suggested that if anticipation occurs as a consequence of ascertainment bias, then it would be equally apparent in father/offspring and mother/offspring pairs, while anticipation confined to one sex of parent indicates some specific genetic or epigenetic event (Ridley et al. 1988). The same reasoning can be applied to linkage studies in complex traits. Note well, however, that not every evidence for paternal or maternal linkage can be immediately treated as genomic imprinting. Differential rates of meiotic recombination in male and female meioses may lead to artefactual differential linkage. To avoid this bias, higher density of markers in the region of putative linkage and multipoint linkage analysis is indicated.

Secondly, parental-sex specific linkage suggests that genomic imprinting may be operating in the etiology of a disease. Genomic imprinting implies that the gene(s) that predispose to a disease, carry different epigenetic marks depending on their parental origin. Genomic imprinting at disease gene(s) opens new opportunities in cloning such gene(s). Several laboratory methods can be applied to direct cloning of differentially imprinted genomic loci, and such methods will be briefly described in the next section. In complex traits, experimental approaches alternative to traditional positional cloning may be of significant importance because linkage analyses often are not able to narrowly define the region of linkage. At present chromosome 18 regions linked to BPAD are clearly too wide (Van Broeckhoven and Verheyen 1999) for the application of positional cloning and expectations of a rapid cloning of disease genes are unrealistic.

Epigenetic studies of chromosome 18 in BPAD may also help understanding the yet unknown disease mechanisms. In a study by Stine et al. (1995), a marker on the short arm of chromosome 18, D18S464, exhibited excess sharing of maternal alleles $(p=.004$ and $p=.02$ for phenotype of bipolar disease and bipolar disease plus recurrent unipolar depression, respectively), but surprisingly this excess sharing was detected in the paternal pedigrees. A similar phenomenon was detected in Nöthen et al. (1999), where evidence for linkage on chromosome $18 p$ was the strongest for a recessive model in the paternal pedigrees (e.g., recessive narrow model, $\mathrm{LOD}=1.67,1.91$, and 1.65 for markers D18S37, S453, and S40, respectively). Markers D18S37 and D18S40 are 17cM and 3cM away from D18S464 in the female-specific genetic map, respectively, which suggests that evidence for linkage may be to the same genetic locus in both studies. In both studies evidence for linkage originated predominantly from the non-affected parent (i.e., the mother). To our knowledge, no experimentally proven mechanism for such a pattern of disease transmission is yet available. It is worthwhile mentioning, however, the example of a susceptibility locus for type 1 diabetes, IDDM2. IDDM2 is represented by allelic variation of a minisatellite polymorphism at the regulatory region of insulin gene (INS). Class I alleles of INS predispose to type 1 diabetes. A particular class I allele exists, however, that does not predispose to the disease when paternally inherited, which is compatible with polymorphic genomic imprinting (Bennett et al. 1997). The paternal effect is observed only when the father's untransmitted allele belongs to class III alleles (Bennett et al. 1997). This putative allelic interaction is similar to an epigenetic phenomenon of paramutation described in plants. It could be the case that in BPAD genetic risk factors on chromosome 18p are regulated by complex interaction btween transmitted and untransmitted alleles in addition to parental- and sex- specific DNA modifications. The above examples of type 1 diabetes and BPAD once again remind that complex disease may be caused by far more complicated mechanisms than the ones identified in more simple genetic diseases such as sickle cell anemia or cystic fibrosis.

\section{EPIGENETICS ASPECTS OF ANTIPSYCHOTIC TREATMENT}

In addition to relevance to major psychiatric disease, epigenetic status of specific genes may be one of the tar- 
gets of antipsychotic neuroleptic treatment as well as one of the mechanisms of the action of neuroleptic medications. The idea that medication may affect DNA methylation is not new, and has been discussed over years in other fields of medicine (Szyf 1996). The epigenetic hypothesis may address one of the most unclear issues in psychopharmacology of why a two to three-week delay is necessary for achieving clinical antipsychotic effect (Bender et al. 1998, Johnstone et al. 1978) when neuroleptics block specific receptors within hours after they get into an organism (Hornykiewicz 1982). Epigenetic changes in the cell are relatively slow and may take weeks or even months to generate such a change in epigenetic regulation (Camus et al. 1990, Varela-Moreiras et al. 1995), which makes it consistent with the delayed antipsychotic effect of neuroleptics. The increasing evidence that epigenetic factors regulate not only the amount of mRNA molecules of a specific gene but also the nuclear location and the time of expression during a specific period in the cell cycle (Riggs and Porter 1996) may lead to uncovering the specific mechanisms of neuroleptic-epigenotype interactions.

Epigenetic characterisation of the genes that encode receptors that are the targets of antipsychotic medications, may also contribute to better differentiation between potential responders and non-responders to a specific drug. There is evidence that the above described $102 \mathrm{C} / \mathrm{T}$ polymorphism at the HTR $2 A$ is a predictor of the clinical response to clozapine (Arranz et al. 1998) and typical neuroleptics (Joober et al. 1999). Response to neuroleptics may be partially determined by the differential expression of HTR $2 A$ epialleles, which results in differential density of serotonin $2 \mathrm{~A}$ receptor in the brain tissues and effectively differential number of target receptors for the antipsychotic drug.

A series of studies have been dedicated to serotonin transporter gene (SLC6A4 or 5-HTT). DNA sequence variation was detected in the upstream regulatory sequence of SLC6A4, and the alleles of this genetic polymorphism was shown to have an effect on gene transcription (Lesch et al. 1996). Lymphoblastoid cells with at least one copy of the short allele ('s') of SLC6A4 demonstrated a significantly lower degree of SLC6A4 expression, serotonin uptake potential and binding in comparison to the homozygotes for the long $\left({ }^{\prime} \mathrm{l}^{\prime}\right)$ allele (Lesch et al. 1996). A recent pharmacogenetic study suggested the putative role of DNA sequence variation in the promoter of SLC6A4 in response to treatment of major depression with fluvoxamine, a selective serotonin re-uptake inhibitor (Smeraldi et al. 1998). The homozygotes ' $1 / 1$ ' as well as heterozygotes ' $\mathrm{s} / \mathrm{l}$ ' were better responders to fluvoxamine in comparison to the 's/ $\mathrm{s}^{\prime}$ homozygotes. Although the results are intriguing, it is not clear why the ' $1 / 1$ ' and ' $s / 1$ ' individuals showed similar response to fluvoxamine, while the earlier functional studies demonstrated that genotype ' $s / \mathrm{l}^{\text {' is much }}$ more similar to ' $\mathrm{s} / \mathrm{s}$ ' in comparison to ' $1 / \mathrm{l}^{\prime}$ ' (Lesch et al. 1996). These discrepancies suggest that there could be tissue specific factors that lead to functional differences between in vitro lymphoblastoid cell lines and in vivo CNS tissues, with a good chance that such factors are epigenetic. The findings that the degree of expression may be involved in the drug response as well as predisposition to bipolar and unipolar disease (Furlong et al. 1998) warrants a detailed analysis of epigenetic regulation of the SLC6A4. It is expected that the SLC6A4 will exhibit a number of variants of epigenetic regulation that may act relatively independently from the DNA sequence-based factors.

\section{FINAL NOTES}

Ten years of intensive molecular genetic searches for DNA mutations that would cause or predispose to major psychosis, unfortunately, have not been very productive. Experimental data of genetic linkage and association studies accumulated over this decade are either controversial or negative. Research strategies that worked relatively well in other complex diseases, such as breast cancer and Alzheimer's disease, turned out to be significantly less efficient in major psychosis. To paraphrase the well-known commandment (Paterson 1998), it looks like "all diseases are complex but some of them are more complex than others". For the "more complex" diseases the epigenetic paradigm could bring new theoretical and experimental opportunities. The criteria for selection of target genes or chromosomal loci for epigenetic studies are straightforward, which include parent-of-origin effect, sex effects, evidence for association with polymorphisms that have no evident role in functioning of a gene, and other epigenetic phenomena.

The above hypotheses can be tested using a series of epigenetic strategies. DNA methylation status in serotonin and dopamine receptor genes can be investigated using pairs of methylation sensitive and insensitive restriction enzyme, such as MspI and HpaII, Cfr9I and SmaI (see http://www.fermentas.com), as well as the more informative approach that utilizes bisulphite-induced modification of genomic DNA (Frommer et al. 1992). If the target gene is unknown, but evidence exists that epigenetic factors are operating (e.g., chromosome 18 in BPAD), screening for epigenetic differences can be performed using at least two techniques. Restriction landmark genomic scanning (RLGS) is a method that employs two-dimensional electrophoresis and allows for simultaneous visualization of a large number of DNA loci (Hayashizaki et al. 1993) including differentially methylated DNA fragments (Kawai et al. 1993). A modification of representational difference analysis can also be applied for cloning of DNA sequences that are subjected to differential DNA methylation. This method is called methylation sensitive representational difference analysis (MS-RDA) (Toyota et al. 1999, Ushijima et al. 1997). 
Another important component of regulation of gene activity is chromatin structure. It has been known for a long time that in addition to DNA methylation, a high degree of gene expression correlates with histone hyperacetylation, while a low degree of such expression is linked to hypoacetylation of histones (Fletcher and Hansen 1996). The proportion of acetylated histones to deacetylated ones in each specific chromosomal region can be detected using anti-acetylated histone antibodies and quantitative polymerase chain reaction (e.g., Coffee et al. 1999). Interestingly, over the last several years relationship between DNA methylation and histone acetylation, two fundamental epigenetic mechanisms, has been established, which was detected that a methylcytosine-binding protein (MeCP2) that binds to methylated DNA, via other proteins attracts histone deacetylases (HDAC1 and HDAC2; Jones et al. 1998, Nan et al. 1998). For a number of genes, DNA methylation and histone acetylation may act synergistically.

Identification of patients to whom epimutations, but not DNA mutations, play an etiopathogenic role would be of a significant importance. Exclusion of the "epigenetic" subgroup of SCZ or BPAD patients from samples would reduce the degree of heterogeneity of major psychosis, and, therefore, increase the power of the more traditional genetic linkage and association studies in the rest of the sample. Additionally, evidence for any epigenetic changes at the candidate genes to major psychosis may lead to new DNA modification-based therapies. Recently, a compound protein consisting of DNA methyltransferase and zinc-finger protein was constructed (Xu and Bestor 1997). The mechanism of action of such a protein consists of the recognition of the target DNA sequence by the zinc-finger protein that is specific for the target sequence and subsequent methylation of the surrounding cytosines by DNA methyltransferase. This design may exhibit a number of advantages in comparison to the more traditional therapeutic approaches, including higher specificity as well as lower toxicity with fewer side effects. If DNA methylation defects are detected in SCZ or BPAD, a specific fusion protein recognising the sites of epimutations and restoring the normal epigenetic patterns can be generated.

\section{ACKNOWLEDGMENTS}

This work was supported by the grants from NARSAD and the Ontario Mental Health Foundation. The author is an OMHF Investigator.

\section{REFERENCES}

Adami G, Babiss LE (1991): DNA template effect on RNA splicing: two copies of the same gene in the same nucleus are processed differently. Embo J 10:3457-3465
Arranz M, Collier D, Sodhi M, Ball D, Roberts G, Price J, Sham P, Kerwin R (1995): Association between clozapine response and allelic variation in 5-HT2A receptor gene. Lancet 346:281-282

Arranz MJ, Munro J, Sham P, Kirov G, Murray RM, Collier DA, Kerwin RW (1998): Meta-analysis of studies on genetic variation in 5-HT2A receptors and clozapine response. Schizophr Res 32:93-99

Asherson P, Mant R, Holmans P, Williams J, Cardno A, Murphy K, Jones L, Collier D, McGuffin P, Owen MJ (1996): Linkage, association and mutational analysis of the dopamine D3 receptor gene in schizophrenia. Mol Psychiatry 1:125-132

Barlow DP. A (1995): Gametic imprinting in mammals. Science 270:1610-1613

Bender CM, Zingg JM, Jones PA (1998): DNA methylation as a target for drug design. Pharm Res 15:175-187

Bennett ST, Wilson AJ, Esposito L, Bouzekri N, Undlien DE, Cucca F, Nistico L, Buzzetti R, Bosi E, Pociot F, Nerup J, Cambon-Thomsen A, Pugliese A, Shield JP, McKinney PA, Bain SC, Polychronakos C, Todd JA (1997): Insulin VNTR allele-specific effect in type 1 diabetes depends on identity of untransmitted paternal allele. The IMDIAB Group. Nature Genet 17:350-352

Bestor TH, Chandler VL, Feinberg AP (1994): Epigenetic effects in eukaryotic gene expression. Develop Genet 15:458-462

Bunzel R, Blumcke I, Cichon S, Normann S, Schramm J, Propping P, Nothen MM (1998): Polymorphic imprinting of the serotonin-2A (5-HT2A) receptor gene in human adult brain. Brain Res Mol Brain Res 59:90-92

Burnet PW, Eastwood SL, Harrison PJ (1996): 5-HT1A and 5-HT2A receptor $m$ RNAs and binding site densities are differentially altered in schizophrenia. Neuropsychopharmacol 15:442-455

Camus AM, Bereziat JC, Shuker DE, Hietanen E, Wild CP, Montesano R, Bartsch H (1990): Effects of a high fat diet on liver DNA methylation in rats exposed to N-nitrosodimethylamine. Carcinogenesis 11:2093-2095

Cargill M, Altshuler D, Ireland J, Sklar P, Ardlie K, Patil N, Lane CR, Lim EP, Kalyanaraman N, Nemesh J, Ziaugra L, Friedland L, Rolfe A, Warrington J, Lipshutz R, Daley GQ, Lander ES (1999): Characterization of single-nucleotide polymorphisms in coding regions of human genes. Nature Genetics 22:231-238

Clifford CP, Nunez DJ (1996): 5HT2A receptor T102C polymorphism and schizophrenia. Lancet 347:1830

Cockett NE, Jackson SP, Shay TL, Farnir F, Berghmans S, Snowder GD, Nielsen DM, Georges M (1996): Polar overdominance at the ovine callipyge locus. Science 273:236-238

Coffee B, Zhang F, Warren ST, Reines D (1999): Acetylated histones are associated with FMR1 in normal but not fragile X-syndrome cells. Nat Genet 22:98-101

Collins JS, Go RC (1997): Disease classification and transmission effects on linkage analyses in the NIMH1 bipolar disorder pedigrees. Genet Epidemiol 14:587-592

Crocq MA, Mant R, Asherson P, Williams J, Hode Y, Mayerova A, Collier D, Lannfelt L, Sokoloff P, Schwartz JC, (1992): Association between schizophrenia and homozygosity at the dopamine D3 receptor gene. J Med Genet 29:858-860 
Crow TJ (1996): 5HT2A receptor, T102C polymorphism, and schizophrenia. Lancet 347:1832

Detera-Wadleigh SD, Badner JA, Berrettini WH, Yoshikawa T, Goldin LR, Turner G, Rollins DY, Moses T, Sanders AR, Karkera JD, Esterling LE, Zeng J, Ferraro TN, Guroff JJ, Kazuba D, Maxwell ME, Nurnberger JI Jr, Gershon ES (1999): A high-density genome scan detects evidence for a bipolar-disorder susceptibility locus on $13 q 32$ and other potential loci on 1q32 and 18p11.2. Proc Natl Acad Sci USA 96:5604-5609

Donald JA, Salmon JA, Adams LJ, Littlejohn T, Maher A, Mitchell PB, Schofield PR (1997): Parental sex effects in bipolar affective disorder pedigrees. Genet Epidemiol 14:611-616

Dubertret C, Gorwood P, Ades J, Feingold J, Schwartz JC, Sokoloff P (1998): Meta-analysis of DRD3 gene and schizophrenia: ethnic heterogeneity and significant association in Caucasians. Am J Med Genet 81:318-322

Erdmann J, Shimron-Abarbanell D, Rietschel M, Albus M, Maier W, Korner J, Bondy B, Chen K, Shih JC, Knapp M, Propping P, Nothen MM (1996): Systematic screening for mutations in the human serotonin-2A (5-HT2A) receptor gene: Identification of two naturally occurring receptor variants and association analysis in schizophrenia. Hum Genet 97:614-619

Falls JG, Pulford DJ, Wylie AA, Jirtle RL (1999): Genomic imprinting: implications for human disease. Am J Pathol 154:635-647

Fletcher TM, Hansen JC (1996): The nucleosomal array: structure/function relationships. Crit Rev Eukaryot Gene Expr 6:149-188

Frommer M, McDonald LE, Millar DS, Collis CM, Watt F, Grigg GW, Molloy PL, Paul CL (1992): A genomic sequencing protocol that yields a positive display of 5methylcytosine residues in individual DNA strands. Proc Natl Acad Sci USA 89:827-831

Furlong RA, Ho L, Walsh C, Rubinsztein JS, Jain S, Paykel ES, Easton DF, Rubinsztein DC (1998): Analysis and meta-analysis of two serotonin transporter gene polymorphisms in bipolar and unipolar affective disorders. Am J Med Genet 81:58-63

Gershon ES, Badner JA, Detera-Wadleigh SD, Ferraro TN, Berrettini WH (1996): Maternal inheritance and chromosome 18 allele sharing in unilineal bipolar illness pedigrees. Am J Med Genet 67:202-207

Greenwood CM, Bull SB (1997): Incorporation of covariates into genome scanning using sib-pair analysis in bipolar affective disorder. Genet Epidemiol 14:635-640

Griffon N, Crocq MA, Pilon C, Martres MP, Mayerova A, Uyanik G, Burgert E, Duval F, Macher JP, Javoy-Agid F, Tamminga CA, Schwartz JC, Sokoloff P (1996): Dopamine D3 receptor gene: organization, transcript variants, and polymorphism associated with schizophrenia. Am J Med Genet 67:63-70

Grigoroiu-Serbanescu M, Martinez M, Nothen MM, Propping P, Milea S, Mihailescu R, Marinescu E (1998): Patterns of parental transmission and familial aggregation models in bipolar affective disorder. Am J Med Genet 81:397-404

Hawi Z, Myakishev MV, Straub RE, O'Neill A, Kendler KS, Walsh D, Gill M (1997): No association or linkage between the 5-HT2A T102C polymorphism and schizophrenia in Irish families. Am J Med Genet 74:370-373
Hayashizaki Y, Hirotsune S, Okazaki Y, Hatada I, Shibata H, Kawai J, Hirose K, Watanabe S, Fushiki S, Wada S, Sugimoto T, Kobayakawa K, Kawara T, Katsuki M, Shibuya T, Mukai T (1993): Restriction landmark genomic scanning method and its various applications. Electrophoresis 14:251-258

Hayward BE, Moran V, Strain L, Bonthron DT (1998): Bidirectional imprinting of a single gene: GNAS1 encodes maternally, paternally, and biallelically derived proteins. Proc Natl Acad Sci USA 95:5475-5480

He L, Li T, Melville C, Liu S, Feng GY, Gu NF, Fox H, Shaw D, Breen G, Liu X, Sham P, Brown J, Collier D, St Clair D (1999): 102T/C polymorphism of serotonin receptor type 2A gene is not associated with schizophrenia in either Chinese or British populations. Am J Med Genet 88:95-98

Henikoff S, Matzke MA (1997): Exploring and explaining epigenetic effects. Trends Genet 13:293-295

Hollick JB, Chandler VL (1998): Epigenetic allelic states of a maize transcriptional regulatory locus exhibit overdominant gene action. Genetics 150:891-897

Holliday R (1996): DNA methylation in eukaryotes: 20 years on. In Russo VEA, Martienssen RA, Riggs AD (eds), Epigenetic Mechanisms of Gene Regulation. Cold Spring Harbor, New York, Cold Spring Harbor Laboratory Press, pp 5-27

Hornykiewicz O (1982): Brain catecholamines in schizophrenia-A good case for noradrenaline. Nature 299:484-486

Inayama $\mathrm{Y}$, Yoneda $\mathrm{H}$, Sakai $\mathrm{T}$, Ishida $\mathrm{T}$, Nonomura $\mathrm{Y}$, Kono Y, Takahata R, Koh J, Sakai J, Takai A, Inada Y, Asaba H (1996): Positive association between a DNA sequence variant in the serotonin $2 \mathrm{~A}$ receptor gene and schizophrenia. Am J Med Genet 67:103-105

Jantzen K, Fritton HP, Igo-Kemenes T, Espel E, Janich S, Cato AC, Mugele K, Beato M (1987): Partial overlapping of binding sequences for steroid hormone receptors and DNase I hypersensitive sites in the rabbit uteroglobin gene region. Nucleic Acids Res 15:4535-52

Jinno Y, Yun K, Nishiwaki K, Kubota T, Ogawa O, Reeve AE, Niikawa N (1994): Mosaic and polymorphic imprinting of the WT1 gene in humans. Nat Genet 6:305-309

Johnstone EC, Crow TJ, Frith CD, Carney MW, Price JS (1978): Mechanism of the antipsychotic effect in the treatment of acute schizophrenia. Lancet 1:848-851

Joober R, Benkelfat C, Brisbois K, Toulouse A, Turecki G, Lal S, Bloom D, Labelle A, Lalonde P, Fortin D, Alda M, Palmour R, Rouleau GA (1999): T102C polymorphism in the 5HT2A gene and schizophrenia: relation to phenotype and drug response variability. J Psychiatry Neurosci 24:141-146

Jones PL, Veenstra GJ, Wade PA, Vermaak D, Kass SU, Landsberger N, Strouboulis J, Wolffe AP (1998): Methylated DNA and MeCP2 recruit histone deacetylase to repress transcription. Nat Genet 19:187-191

Joyce JA, Schofield PN (1998): Genomic imprinting and cancer. Mol Pathol 51:185-190

Kato MV, Shimizu T, Nagayoshi M, Kaneko A, Sasaki MS, Ikawa Y (1996): Genomic imprinting of the human serotonin-receptor (HTR2) gene involved in development of retinoblastoma. Am J Hum Genet 59:1084-1090

Kato MV, Ikawa Y, Hayashizaki Y, Shibata H (1998): Paternal imprinting of mouse serotonin receptor $2 \mathrm{~A}$ gene 
Htr2 in embryonic eye: a conserved imprinting regulation on the RB/Rb locus. Genomics 47:146-148

Kato T, Winokur G, Coryell W, Keller MB, Endicott J, Rice J (1996): Parent-of-origin effect in transmission of bipolar disorder. Am J Med Genet 67:546-550

Kawai J, Hirotsune S, Hirose K, Fushiki S, Watanabe S, Hayashizaki Y (1993): Methylation profiles of genomic DNA of mouse developmental brain detected by restriction landmark genomic scanning (RLGS) method. Nucleic Acids Res 21:5604-5608

Kidd KK (1993): Associations of disease with genetic markers: Deja vu all over again. Am J Med Genet 48:71-73

Kouzmenko AP, Hayes WL, Pereira AM, Dean B, Burnet PW, Harrison PJ (1997): 5-HT2A receptor polymorphism and steady state receptor expression in schizophrenia. Lancet 349:1815

Krawczak M, Ball EV, Cooper DN (1998): Neighboring-nucleotide effects on the rates of germ-line single-base-pair substitution in human genes. Am J Hum Genet 63:474-88

Lesch KP, Bengel D, Heils A, Sabol SZ, Greenberg BD, Petri S, Benjamin J, Muller CR, Hamer DH, Murphy DL (1996): Association of anxiety-related traits with a polymorphism in the serotonin transporter gene regulatory region. Science 274:1527-1531

Lewis R, Kapur S, Jones C, DaSilva J, Brown GM, Wilson AA, Houle S, Zipursky RB (1999): Serotonin 5-HT2 receptors in schizophrenia: A PET study using [18F]setoperone in neuroleptic-naive patients and normal subjects. Am J Psychiatry 156:72-78

Lin JP, Bale SJ (1997): Parental transmission and D18S37 allele sharing in bipolar affective disorder. Genet Epidemiol 14:665-668

Lopez AJ (1998): Alternative splicing of pre-mRNA: Developmental consequences and mechanisms of regulation. Annu Rev Genet 32:279-305

Lundstrom K, Turpin MP (1996): Proposed schizophreniarelated gene polymorphism: Expression of the Ser9Gly mutant human dopamine D3 receptor with the Semliki Forest virus system. Biochem Biophys Res Commun 225:1068-1072

McMahon FJ, Stine OC, Meyers DA, Simpson SG, DePaulo JR (1995): Patterns of maternal transmission in bipolar affective disorder. Am J Hum Genet 56:1277-1286

McMahon FJ, Hopkins PJ, Xu J, McInnis MG, Shaw S, Cardon L, Simpson SG, MacKinnon DF, Stine OC, Sherrington R, Meyers DA, DePaulo JR (1997): Linkage of bipolar affective disorder to chromosome 18 markers in a new pedigree series. Am J Hum Genet 61:1397-1404

Meador-Woodruff JH, Haroutunian V, Powchik P, Davidson M, Davis KL, Watson SJ (1997): Dopamine receptor transcript expression in striatum and prefrontal and occipital cortex. Focal abnormalities in orbitofrontal cortex in schizophrenia. Arch Gen Psychiatry 54:1089-1095

Moen PT Jr, Smith KP, Lawrence JB (1995): Compartmentalization of specific pre-mRNA metabolism: an emerging view. Hum Mol Genet 4(Spec No):1779-1789

Nan X, Ng HH, Johnson CA, Laherty CD, Turner BM, Eisenman RN, Bird A (1998): Transcriptional repression by the methyl-CpG-binding protein MeCP2 involves a histone deacetylase complex. Nature 393:386-389
Nimchinsky EA, Hof PR, Janssen WGM, Morrison JH, Schmauss C (1997): Expression of dopamine D3 receptor dimers and tetramers in brain and in transfected cells. J Biol Chem 272:29229-29237

Nöthen MM, Cichon S, Rohleder H, Hemmer S, Franzek E, Fritze J, Albus M, Borrmann-Hassenbach M, Kreiner R, Weigelt B, Minges J, Lichtermann D, Maier W, Craddock N, Fimmers R, Holler T, Baur MP, Rietschel M, Propping P (1999): Evaluation of linkage of bipolar affective disorder to chromosome 18 in a sample of 57 German families. Mol Psychiatry 4:76-84

O'Donovan MC, Owen MJ (1999): Candidate-gene association studies of schizophrenia. Am J Hum Genet 65:587-592

Ohlsson R, Tycko B, Sapienza C (1998): Monoallelic expression: 'There can only be one'. Trends Genet 14:435-438

Paterson A (1998): All alleles are equal, but some alleles are more equal than others. Molec Psychiat 3:212

Petronis A (1999): The regulation of D2 dopamine receptor expression: epigenetic factors should not be forgotten. Molec Psychiat 4(3):212-213

Petronis A, Paterson AD, Kennedy JL (1999): Schizophrenia: An epigenetic puzzle? Schizophr Bull 25:639-655

Petronis A, Vincent JB, Surh LC, Ashizawa T, Kennedy JL (in press): Polyglutamine-containing proteins in schizophrenia: an effect of lymphoblastoid cells? Molec Psychiat

Popendikyte V, Laurinavicius A, Paterson AD, Macciardi F, Kennedy JL, Petronis A (1999): DNA methylation at the putative promoter region of the human dopamine D2 receptor gene. NeuroReport 10:1249-1255

Rice J (1997): Genetic analysis of bipolar disorder: summary of GAW10. Genet Epidemiol 14:549-561

Ridley RM, Frith CD, Crow TJ, Conneally PM (1988): Anticipation in Huntington's disease is inherited through the male line but may originate in the female. J Med Genet 25:589-595

Riggs AD, Porter TN (1996): Overview of epigenetic mechanims. In Epigenetic mechanisms of gene regulation. In Russo VEA, Martienssen RA, Riggs AD (eds), Cold Spring Harbor, NY, Cold Spring Harbor Laboratory Press, pp 29-45

Saluz HP, Jiricny J, Jost JP (1986): Genomic sequencing reveals a positive correlation between the kinetics of strand-specific DNA demethylation of the overlapping estradiol/glucocorticoid-receptor binding sites and the rate of avian vitellogenin mRNA synthesis. Proc Natl Acad Sci USA 83:7167-7171

Schmauss C, Haroutunian V, Davis KL, Davidson M (1993): Selective loss of dopamine D3-type receptor mRNA expression in parietal and motor cortices of patients with chronic schizophrenia. Proc Natl Acad Sci USA 90:8942-8946

Schmauss C (1996): Enhanced cleavage of an atypical intron of dopamine D3-receptor pre-mRNA in chronic schizophrenia. J Neurosci 16:7902-7909

Sharpe D (1997): Of apples and oranges, file drawers and garbage: Why validity issues in meta-analysis will not go away. Clin Psychol Rev 17:881-901

Shemer R, Razin A (1996): Establishment of imprinted methylation patterns during development. In Russo VEA, Martienssen RA, Riggs AD (eds), Epigenetic Mecha- 
nisms of Gene Regulation. Cold Spring Harbor, New York, Cold Spring Harbor Laboratory Press, pp 215-229

Smeraldi E, Zanardi R, Benedetti F, Di Bella D, Perez J, Catalano M (1998): Polymorphism within the promoter of the serotonin transporter gene and antidepressant efficacy of fluvoxamine. Molec Psychiat 3:508-511

Solter D (1998): Imprinting. Int J Dev Biol 42(7 Spec No):951-954

Spurlock G, Heils A, Holmans P, Williams J, D'Souza UM, Cardno A, Murphy KC, Jones L, Buckland PR, McGuffin P, Lesch KP, Owen MJ (1998a): A family based association study of T102C polymorphism in 5HT2A and schizophrenia plus identification of new polymorphisms in the promoter. Molec Psychiat 3:42-49

Spurlock G, Williams J, McGuffin P, Aschauer HN, Lenzinger E, Fuchs K, Sieghart WC, Meszaros K, Fathi N, Laurent C, Mallet J, Macciardi F, Pedrini S, Gill M, Hawi Z, Gibson S, Jazin EE, Yang HT, Adolfsson R, Pato CN, Dourado AM, Owen MJ (1998b): European Multicentre Association Study of Schizophrenia: A study of the DRD2 Ser311Cys and DRD3 Ser9Gly polymorphisms. Am J Med Genet 81:24-28

Stine OC, Xu J, Koskela R, McMahon FJ, Gschwend M, Friddle C, Clark CD, McInnis MG, Simpson SG, Breschel TS, Vishio E, Riskin K, Feilotter H, Chen E, Shen S, Folstein S, Meyers DA, Botstein D, Marr TG, DePaulo RJ (1995): Evidence for linkage of bipolar disorder to chromosome 18 with a parent-of-origin effect. Am J Hum Genet 57:1384-1394

Szyf M (1996): The DNA methylation machinery as a target for anticancer therapy. Pharmacol Ther 70:1-37.

Toyota M, Ho C, Ahuja N, Jair KW, Li Q, Ohe-Toyota M, Baylin SB, Issa JP (1999): Identification of differentially methylated sequences in colorectal cancer by methylated CpG island amplification. Cancer Res 59:2307-2312

Truss M, Chalepakis G, Pina B, Barettino D, Bruggemeier U, Kalff M, Slater EP, Beato M (1992): Transcriptional control by steroid hormones. J Steroid Biochem Mol Biol 41:241-248

Ushijima T, Morimura K, Hosoya Y, Okonogi H, Tatematsu M, Sugimura T, Nagao M (1997): Establishment of methylation-sensitive-representational difference analysis and isolation of hypo- and hypermethylated genomic fragments in mouse liver tumors. Proc Natl Acad Sci USA 94:2284-2289

Van Broeckhoven C, Verheyen G (1998): Chromosome 18 workshop. Psychiatr Genet 8:97-108

Van Broeckhoven C, Verheyen G (1999): Report on the Chro- mosome 18 workshop. Am J Med Genet (Neuropsychiatric Genetics) 88:263-270

Varela-Moreiras G, Ragel C, Perez de Miguelsanz J (1995): Choline deficiency and methotrexate treatment induces marked but reversible changes in hepatic folate concentrations, serum homocysteine and DNA methylation rates in rats. Am Coll Nutr 14:480-485

Williams J, Spurlock G, McGuffin P, Mallet J, Nothen MM, Gill M, Aschauer H, Nylander PO, Macciardi F, Owen MJ (1996): Association between schizophrenia and T102C polymorphism of the 5-hydroxytryptamine type 2a-receptor gene. European Multicentre Association Study of Schizophrenia (EMASS) Group. Lancet 347:1294-1296

Williams J, McGuffin P, Nothen M, Owen MJ (1997): Metaanalysis of association between the 5-HT2a receptor T102C polymorphism and schizophrenia. EMASS Collaborative Group. European Multicentre Association Study of Schizophrenia. Lancet 349:1221

Williams J, Spurlock G, Holmans P, Mant R, Murphy K, Jones L, Cardno A, Asherson P, Blackwood D, Muir W, Meszaros K, Aschauer H, Mallet J, Laurent C, Pekkarinen P, Seppala J, Stefanis CN, Papadimitriou GN, Macciardi F, Verga M, Pato C, Azevedo H, Crocq MA, Gurling H, Kalsi G, Curtis D, McGuffin P, Owen MJ (1998): A meta-analysis and transmission disequilibrium study of association between the dopamine D3 receptor gene and schizophrenia. Molec Psychiat 3:141149

Xu G-L, Bestor TH (1997): Cytosine methylation targetted to pre-determined sequences. Nature Genet 17:376-379

Xu Y, Goodyer CG, Deal C, Polychronakos C (1993): Functional polymorphism in the parental imprinting of the human IGF2R gene. Biochem Biophys Res Commun 197:747-54

Yang AS, Jones PA, Shibata A (1996): The mutational burden of 5-methylcytosine. In Russo VEA, Martienssen RA, Riggs AD (eds), Epigenetic Mechanisms of Gene Regulation. Cold Spring Harbor, New York, Cold Spring Harbor Laboratory Press, pp 77-94

Yokomori N, Moore R, Negishi M (1995): Sexually dimorphic DNA demethylation in the promoter of the Slp (sex-limited protein) gene in mouse liver. Proc Natl Acad Sci USA 92:1302-1306

Zirbel RM, Mathieu UR, Kurz A, Cremer T, Lichter P (1993): Evidence for a nuclear compartment of transcription and splicing located at chromosome domain boundaries. Chromosome Res 1:93-106 